\title{
OCCURRENCE OF TORVONEUSTES (CROCODYLOMORPHA, METRIORHYNCHIDAE) IN MARINE JURASSIC DEPOSITS OF OAXACA, MEXICO
}

\author{
JAIR I. BARRIENTOS-LARA \\ Posgrado en Ciencias Biológicas, Instituto de Geología, Universidad Nacional Autónoma de México, Circuito de la \\ Investigación S/N, Ciudad Universitaria, Delegación Coyoacán, Distrito Federal, 04510, México.j4ir@me.com
}

\section{YANINA HERRERA, MARTA S. FERNÁNDEZ}

División Paleontología Vertebrados, Unidades de Investigación Anexo Museo, Facultad de Ciencias Naturales y Museo, Universidad Nacional de La Plata, Av. 60 y 122, B1900AVW, La Plata, Argentina.

yaninah@fcnym.unlp.edu.ar,martafer@fcnym.unlp.edu.ar

\section{JESÚS ALVARADO-ORTEGA}

Instituto de Geología, Universidad Nacional Autónoma de México, Circuito de la Investigación s/n, Ciudad Universitaria, Delegación Coyoacán, Distrito Federal, 04510, México.alvarado@geologia.unam.mx

\begin{abstract}
IGM 9026 is a singular fossil collected at the beginning of the 20th century in an improperly documented site within the Tlaxiaco Basin, near to Tlaxiaco town, Oaxaca, Mexico. The age of the site was suggested as being early Cretaceous. This specimen is the holotype of Plesiosaurus (Polypticodon) mexicanus, which later was identified as a possible late Jurassic marine crocodylomorph of the family Metriorhynchidae, and consequently it was referred as ?Cricosaurus mexicanus. The present study provides a re-description of this fossil based on a microscopic analysis and the use of white and UV lights; these analyses led to the discovery of peculiar dental characters diagnostic of the genus Torvoneustes. This finding supports the re-classification of IGM 9026 under a new nominal combination as Torvoneustes mexicanus. Along the Tlaxiaco Basin, the fossil preservation mode and lithological composition observed in IGM 9026 only occur in the marine vertebrates recently discovered in Yosobé, a Kimmeridgian shale outcrop characterized by clay calcareous nodules that belong to the Sabinal Formation, near Tlaxiaco town. This peculiarity suggests that $T$. mexicanus could represent an additional element of the Kimmeridgian vertebrate assemblage recovered in this geological unit. The two nominal species of Torvoneustes were collected in Kimmeridgian marine deposits of England; hence, this finding expands the geographical distribution of Torvoneustes all along the Tethys Sea, from its Eastern/European to western/ Caribbean domains.
\end{abstract}

Keywords: Torvoneustes, Plesiosaurus mexicanus, hispanic corridor, Kimmeridgian, Tlaxiaco Basin, Sabinal Formation.

RESUMO - O exemplar IGM 9026 é um fóssil singular coletado no princípio do século 20 em um sítio pouco conhecido da Bacia Tlaxiaco, situado próximo a cidade de Tlaxiaco, Estado de Oaxaca, sul do México, cuja idade foi vagamente sugerida como do Eocretáceo. Originalmente, este único exemplar é holótipo do plesiossauro Plesiosaurus (Polypticodon) mexicanus. Mais tarde, ele foi identificado como um possível crocodilomorfo marinho do Jurássico Superior da família Metriorhynchidae, e portanto, foi referido como ?Cricosaurus mexicanus. O presente estudo proporciona uma nova descrição deste fóssil baseado em uma análise microscópica, uso de luzes brancas e UV, que levou à descoberta de caracteres dentários únicos neste exemplar, que coincidem com aqueles do gênero Torvoneustes. Este achado apoia a reclassificação de IGM 9026 a partir de uma nova combinação nominal como Torvoneustes mexicanus. Ao longo da Bacia de Tlaxiaco, o modo de conservação dos fósseis e a composição litológica observada em IGM 9026 somente se repetem nos vertebrados marinhos da Formação Sabinal, recentemente descobertos nas proximidades de Tlaxiaco. Esta peculiaridade sugere que T. mexicanus poderia representar um elemento adicional da associação de vertebrados fósseis do Kimmeridgiano da dita unidade geológica. As duas espécies nominais de Torvoneustes foram coletadas em jazimentos Kimeridgianos da Inglaterra, de forma que o presente achado amplia a distribuição geográfica do gênero ao longo do Mar de Tétis, desde a região Oriental na Europa até o seu domínio Ocidental no Caribe.

Palavras-chave: Torvoneutes, Plesiosaurus mexicanus, corredor hispânico, Kimmeridgiano, BaciaTlaxiaco, Formação Sabinal.

\section{INTRODUCTION}

Metriorhynchidae is a family of Middle Jurassic-Early Cretaceous marine crocodylomorphs (Wagner, 1858; Eudes-Deslongchamps, 1867-1869; Fraas, 1902; Andrews, 1913; Young, 1948; Pol \& Gaparini, 2009; Cau \& Fanti,
2011; Parrilla-Bel et al., 2013; Young et al., 2014; Herrera et al., 2015; Chiarenza et al., 2015). A number of peculiar adaptative features allowed the successful permanent marine life of this group. Among these, the most remarkable features are the presence of paddle-like forelimbs, hypocercal tail, osteoporotic like bone tissue, occurrence of large and highly 
vascularised nasal salt glands draining toward the preorbital fossa, as well as the reduction of the olfactory tract and bulbs (e.g. Hua \& Bruffenil, 1996; Fernández \& Gasparini, 2000; Young et al., 2010; Herrera et al., 2013). Fossils of these crocodylomorphs have been collected in Europe, as well as in North and South America (e.g. Gasparini \& Chong Díaz, 1977; Gasparini \& Iturralde-Vinent, 2006; Buchy et al., 2007; Wilkinson et al., 2008; Young et al., 2013a, b; Herrera et al., 2015). Up to date, this family includes about 13 genera and 30-40 species gathered in two subfamilies, Metriorhynchinae and Geosaurinae, in which the Rhacheosaurini and Geosaurini constitute the more derived tribes, respectively (e.g. Young et al., 2013a, b).

Recently, an Aalenian-Bajocian (Middle Jurassic) metriorhynchoid, collected in the marine calcareous sandstones of the Snowshoe Formation exposed in Oregon, USA, was described by Wilberg (2015) under the name Zoneait nargorum. Although this author concluded that this ancient thalattosuchian is the sister taxon to Metriorhynchidae, the abundance and diversity of this family are still comparatively low in North America, where its occurrence is restricted to Mexico and Cuba.

Three incomplete and poorly preserved metriorhynchids have been reported from Cuba. Gasparini \& Iturralde-Vinent (2001, 2006) concluded that the first is an indeterminate representative of Geosaurus Cuvier, 1824; the second is an indeterminate metriorhynchid; and the third is an indeterminate talattosuchian. Recently, Iturralde-Vinent \& Ceballos-Izquierdo (2015) proposed that the first two specimens belong to Cricosaurus Wagner, 1858. Unfortunately, as the last authors noted, these taxonomic determinations are inconclusive because in addition to their poor preservation, these fossils suffered strong damages during their chemical preparation. The third of these Cuban specimens is an indeterminate Metriorhynchinae (Young \& Andrade, 2009).

In Mexico the abundance and diversity of metriorhynchids is higher than in Cuba; therefore, this country has become increasingly important for the study of these ancient crocodylomorph. Since a little more than a decade, an increasing number of fossils of this family have been collected and carefully studied. Buchy (2007) provided a detailed overview of the metriorhynchids from Late Jurassic deposits of Mexico. These include Cricosaurus vignaudi Frey, Buchy, Stinnesbeck \& López-Oliva, 2002, from the middle Tithonian deposits of La Pimienta Formation, near Mazatepec, Puebla; Cricosaurus saltillensis Buchy, Vignaud, Frey, Stinnesbeck \& González, 2006, from Sierra de Buñuelas, near Gómez Farías, Coahuila; a fragmentary rostrum of Dakosaurus sp. from Kimmeridgian deposits of La Casita Formation, near San Juan de los Dolores, Coahuila (Buchy, 2008a); and other remains of indeterminate metriorhynchids collected in outcrops of $\mathrm{La}$ Casita and La Caja formations along Coahuila and Nuevo León.

Buchy (2008b) also identified an additional possible Jurassic Mexican metriorhynchid specimen, based on a resin mold of an intriguing fossil thought to be lost, which actually is cataloged as IGM 9026 into the Colección Nacional de
Paleontología at Instituto de Geología, Universidad Nacional Autónoma de México (Figures 1-2). In fact, this specimen was collected and originally studied by Wieland (1910), who identified it as a plesiosaur that he named Plesiosaurus (Polypticodon) mexicanus. Unfortunately, the site where IGM 9026 was collected within Oaxaca State is not properly documented and its age was just vaguely designated as early Cretaceous. Afterward, Young et al. (2010, p. 852) suspected that this single and holotype specimen could belong to the genus Cricosaurus; therefore, they referred it as ?Cricosaurus mexicanus (also see Buchy et al., 2013).

Recently, numerous fossil remains of Kimmeridgian marine crocodylomorphs have been collected in the Llano Yosobé, near Tlaxiaco, Oaxaca, Mexico (Alvarado-Ortega et al., 2014). IGM 9026 was meticulously examined during the comparative study of these new fossils. Such an exercise revealed some previously unreported tooth characters, which support the taxonomical re-assignation of IGM 9026 as part of the genus Torvoneustes Andrade, Young, Desojo \& Brusatte, 2010, as well as the setting-up of a new nominal combination for this specimen. The aim of this study is to describe these newly discovered characters, to support the re-assignation of IGM 9026, and to explore some of the biogeographical implications of this finding.

\section{MATERIAL AND METHODS}

A comparative study of Jurassic marine crocodiles, including those newly discovered near Tlaxiaco (AlvaradoOrtega et al., 2014), established the mandatory review of IGM 9026 previously collected in the vicinity of this village of State of Oaxaca, Mexico. Given its unique nature and its designation as holotype of Plesiosaurus (Polypticodon) mexicanus, IGM 9026 cannot be prepared or altered in anyway. Therefore, in this study, IGM 9026 was observed under stereoscopic microscope and high resolution color and gray-scale photographs; these viewings were made under white light and ultraviolet light of short wave $(254 \mathrm{~nm})$, before and after its coating with ammonium chloride and magnesium-smoke. These procedures allowed us to recognize some structures that had not been observed before by other authors (Wieland, 1910; Buchy, 2008b).

Anatomical abbreviations. The anatomical nomenclature adopted in this study, as well as the anatomical abbreviations that appear in Figure 1, follow previous studies dealing with the anatomical description of metriorhynchids (e.g. Young et al., 2010, 2013a, b).

Institutional abbreviations. The fossil specimens used in this work with comparative purposes are included in the following scientific collections: BRSMG, Bristol City Museum and Art Gallery, Bristol; IGM, Colección Nacional de Paleontología, Instituto de Geología, Universidad Nacional Autónoma de México; MACN, Museo Argentino de Ciencias Naturales "Bernandino Rivadavia", Buenos Aires, Argentina; MJCM, Museo de Ciencias Naturales y Antropológicas "Juan Cornelio Moyano" Mendoza, Argentina; MJML, Museum of Jurassic Marine Life, Kimmeridge, Dorset, UK; MLP, Museo de La 
Plata, La Plata, Argentina; MOZ, Museo Provincial de Ciencias Naturales "Prof. Dr. Juan Augusto Olsacher", Zapala, Neuquén, Argentina; MUDE, Museo del Desierto, Saltillo, Coahuila, Mexico; UANL FCT, Facultad de Ciencias de la Tierra, Universidad Autónoma de Nuevo León, Linares, Mexico.

Comparative material. The following specimens were used with comparative purposes in this work: Cricosaurus araucanensis (Gasparini \& Dellapé, 1976): MLP 72-IV-71 (holotype), complete skull, postcranial skeleton; MACN N 64, anterior skull fragment; MACN N 95, complet skull and cervical vertebrae. Cricosaurus lithographicus Rusconi, 1948: MOZ-PV5787 (holotype), complete skull, jaws and postcranial elements. Cricosaurus saltillensis (Buchy, Vignaud, Frey, Stinnesbeck \& González González, 2006): MUDE CPC 218 (holotype), posterior fragment of skull, jaws and first cervical vertebrae. Cricosaurus vignaudi (Frey, Buchy, Stinnesbeck \& López-Oliva, 2002): cast of UANL FCT-R1 (holotype), skull, jaws and first cervical vertebrae. Dakosaurus andinensis Vignaud \& Gasparini, 1996: MOZ- 6146 (holotype), skull and jaws. Dakosaurus sp.: MUDE CPC 201, rostral fragment (reported in Buchy et al., 2008). Purranisaurus potens Rusconi, 1948: MJCM PV 2060 (holotype), posterior parts of the skull and a fragment of the right jaw.

\section{SYSTEMATIC PALEONTOLOGY}

\author{
Family METRIORHYNCHIDAE Fitzinger, 1843 \\ Subfamily GEOSAURINAE Lydekker, 1889 \\ Tribe GEOSAURINI Lydekker, 1889
}

\section{Torvoneustes Andrade, Young, Desojo \& Brusatte, 2010}

Type species. Torvoneustes carpenteri (Wilkinson et al., 2008) Andrade, Young, Desojo \& Brusatte, 2010. Originally, this was named as Dakosaurus carpenteri Wilkinson, Young \& Benton, 2008; the actual authorships is in attention to recommendation 67B of the International Code of Zoological Nomenclature (International Commission on Zoological Nomenclature, 1999). The two specimens known of this species are from the upper Kimmeridgian marine deposits of the lower Kimmeridge Clay Formation, at Westbury, Wiltshire, England.

Additional species. Torvoneustes coryphaeus Young, Andrade, Etches \& Beatty, 2013, from lowermost Kimmeridgian marine deposits of the lower Kimmeridge Clay Formation, at Studley Grange landfill, Lydiard Tregoze, Wiltshire, England.

Torvoneustes mexicanus (Wieland, 1910) comb. nov. (Figures 1-3)

Holotype. IGM 9026, fragment of cranium including part of the maxillae and dentaries showing 12 teeth in oclussal position, and splenials forming the mandibular symphysis (Figures 1-2).

Type locality and horizon. Wieland's (1910) locality, an unsuitably documented site in the north of the way to Putla, about $6 \mathrm{~km}$ to south-southwest from Tlaxiaco town, Oaxaca, Mexico (Figure 4). Originally, the age of this locality was designated as Neocomian (Wieland, 1910); later, Buchy (2008b) suggested that it is more likely to be Jurassic. Although the Wieland's locality is unprecise, in this work we suggest that IGM 9026 is a Kimmeridgian specimen from the Sabinal Formation deposits, near Tlaxiaco town, Oaxaca, Mexico (see discussion section in this manuscript).

Diagnosis. Torvoneustes species with a unique combination of characters, including robust teeth lingually curved with bicarinated conical crown, carinae bearing microscopic isomorphic denticles well defined (microziphodont condition); acute tooth crown apices; tooth enamel on basal two-thirds of the crown are heavily ornamented with long and thick apicobasal ridges that are uniformly spaced to each other; ridges near to the crown apex become short, drop-shaped tubercles randomly distributed, anatosmosed, and extended up to the carinae.

Description. We agree with the general description of bones preserved in IGM 9026 published by Buchy (2008b). The fragmented specimen is $84.94 \mathrm{~mm}$ high and $94.54 \mathrm{~mm}$ long. Teeth along the maxillae and dentaries are curved in posteromedial direction. Although, IGM 9026 is preserved in three dimensions and bones of both sides are present, the cortical surfaces of maxillae and dentaries are eroded and their external features are partially destroyed. In the left side of the specimen, this defect is so extensive that the large part of these bones and their teeth are not preserved (Figure 1D). In lateral view, the maxilla remain preserved is a long rectangular fragment of about $18.68 \mathrm{~mm}$ high. The cross sections of those bones are well exposed in posterior view; here, the maxillae are C-shaped and enclose a large ovoid nasal cavity (Figure 1C) previously identified by Buchy (2008b). A cross section of an empty dental alveolus preserved in the right maxilla is a large, ovoid hole encased in bone suggesting that this cavity is inclined forward as it happens with the tooth crowns preserved in this bone. In lateral view, the dentary fragment preserved is also a long rectangular structure, about $29.59 \mathrm{~mm}$ high. The reaction of bones preserved in IGM 9026 to UV light clearly reveals the presence of a deep surangulodentary groove (Figures 1B-C). In anterior view, the cross section of the right dentary is $\mathrm{V}$-shape with two teeth exposed inside; the functional tooth is badly preserved while the other, a replacement tooth, preserves the fine details of its enamel tooth ornamentation (Figure 1E). The splenial bones can be seen in the cross sections exposed on the anterior and posterior views of IGM 9026. In posterior view, the right splenial is almost totally covered by recrystalized sediments. In right view, a small part of the left splenial is exposed (Figure 1D); this corresponds to the "possible fragment of the left mandibular ramus" identified by Buchy (2008b, fig. 3). These are flat high bones located medially to the dentaries, and sutured together along the midline to form part of the mandibular symphysis. The thecodont tooth implantation is exposed in the anterior and posterior surfaces of IGM 9026. A total of 12 teeth are preserved. Five maxillary and four dentary functional teeth are exposed in lateral view, on the right side 
of the preserved skull (Figure 1B). In anterior and posterior views, the longitudinal sections of two functional dentary teeth are exposed, as well as a well-preserved replacement tooth (in the anterior view of these surfaces). The occlusion of teeth on dentary and maxillae follows an interdigitated pattern. The functional teeth of both bones are irregular in size but they seem to be separated by relative small and uniform interalveolar spaces, which seem to be close to one half of the alveolar length. In those teeth that expose the crown apex, this terminal tip is acute (Figure 2). It is possible to define the conic and curve shape of the robust teeth of IGM 9026 based on two facts. On one hand, the tips of all the exposed teeth are lingually bent and therefore covered by sediment or below the bones (Figure 1B). On the other hand, this curvature is obvious in the longitudinal section of the functional tooth preserved on the posterior broken surface of right dentary (Figures 1C-D). Based on the longitudinal section, the tooth has no constriction at the crown-root transition.

Tooth enamel covers the entire crowns. The anterior and posterior edges of the crown of both functional and replacement teeth have continuous cariane running from the bottom up to the crown apex. The tooth enamel on labial crown surface show two different ornamental elements; long and isolated apicobasal ridges aligned almost in parallel to each other that cover the basal two-thirds of the crown; in the apical end such ridges become short, discontinuous, and are randomly distributed, forming an anatosmosed pattern that extends up to the carinae; hence, the crown apex seems to be covered with small, drop-shaped, irregularly distributed tubercles (Figures 2A-B).

Along the entire lenght of the mesial and distal carinae, there are true denticles (Figure 2C). These denticles are regular in shape, size, and distribution; the lengths of their bases range around $142 \mu \mathrm{m}$ and the denticle density (=\# denticles $/ 5 \mathrm{~mm}$ ) is about 30 . The features of these denticles show that IGM 9026 teeth have the microziphodont pattern only in the basal two-thirds of the crown. On the other hand, the superficial enamel ornaments reach the carinae of the crown apical end, showing the false-ziphodont pattern described by Andrade et al. (2010) and Young et al. (2013a).

Remarks. Buchy (2008b, p. 521) noted on "the architecture of the rostrum and constituting bones, as well as the tooth morphology" of IGM 9026 enough evidences to consider this as a crocodylomorph thalattosuchian belonging to subfamily Metriorhynchinae (family Metriorhynchidae). Later, Buchy et al. (2013,p. 18) claimed that "the dental and rostral morphology" of this specimen "is consistent with Cricosaurus: procumbent, uncompressed crowns with fine apicobasally aligned ridges; with a tubular snout; the dentary and maxilla parallel; and lacking denticulated carinae"; therefore this specimen was tentatively referred as ?Cricosaurus mexicanus (Young et al., 2010 , p. 852, tbl. A1). Unlike these previous observations, this paper shows that IGM 9026 has some ornamental characters with important implications for its subfamiliar and generic identification. IGM 9026 shows some remarckable characters considered in previous phylogenetic essays (characters 131-1, 135-2, 167-2, 168-2, 169-2 and 170-2, in Herrera et al., 2015; also see Young et al., 2012; Andrade et al., 2010; among others), which include the presence of: (i) alveoli longer than the nearby interaleveolar spaces (Figure 1B); (ii) a deep surangulodentary groove along the dentary bone (Figure 1C); (iii) bicarinated teeth (Figures 2, 3); (iv) denticles well defined and homogeneously distributed all along the carinae (Figure 2) [= true ziphodonty sensu Prasad \& Broin (2002)]. Among metriorhynchids, the characters 1 and 2 are synapomorphies of the tribe Geosaurini, while 3 and 4 are present only in the most derived geosaurinis. According to Herrera et al. (2015), the tribe Geosaurini includes Purranisaurus potens Rusconi, 1948, from the upper Tithonian-lower Berriasian section of the Vaca Muerta Formation, Mendoza, Argentina; Plesiosuchus manselii (Hulke, 1870), from the upper Kimmeridgian to lower Tithonian deposits of England, and possibly also Spain (Ruíz-Omeñaca et al., 2010; Young et al., 2012); Dakosaurus (Quenstedt, 1843), represented by two nominal species and numerous ideterminate specimens from the upper Kimmeridgian to lower Berriasian marine deposits of Europe (England, France, Germany, Russia and Switzerland), South America (Argentina), and probably Mexico (see Vignaud \& Gasparini 1996; Buchy, 2007, 2008a; Young et al., 2012; among others); at least three nominal species of Geosaurus from the Tithonian to Valanginian deposits of Europe (Debelmas \& Strannoloubsky, 1957; Young \& Andrade, 2009; Young et al., 2013b; among others); and two nominal species of Torvoneustes from the Kimmeridgian deposits of England and some late Oxfordian specimen from England referred to this genus (Andrade et al., 2010; Young et al., 2013b). IGM 9026 cannot belong to genus Cricosaurus because even though the species of this genus have non-, uni, or even bicarinated teeth, none of them have denticles along the carinae (= non-ziphodont condition). Unfortunatelly, Purranisaurus is not comparable with IGM 9026 because the teeth of this species are unknown (its inclusion within Geosaurini is based on diagnostic characters of the skull that are unknown in IGM 9026). Dakosaurus has macroziphodont teeth (denticles are distinctively large and naked-eye observable), whereas other geosaurins and IGM 9026 have microziphodont teeth (heights of these denticles are smaller than $300 \mu \mathrm{m})$ (e.g. Young et al., 2012). Plesiosuchus manselii and a putative unnamed close taxon, refered as "indeterminate Plesiosuchina" by Young et al. (2012, 2014a) and Chiarenza et al. (2015), lack the dual pattern of the tooth enamel ornamentation herein described along teeth of IGM 9026, in which the long apicobasal ridges present in the basal part of the crown becomes in the anastomosis of small drop-shaped tubercles on the crown apex; enamel is smooth all along the tooth crown in Plesiosuchus manselii while it is enterily cover with stout apicobasal ridges in the "indeterminate Plesiosuchina" (Young et al., 2012; Chiarenza et al., 2015). The strongly lateromedially compressed teeth with tri-faceted crown labial surface, already recorded in the species of Geosaurus, is easily differentiable from other Geosaurini taxa and IGM 9026, which have conical or slightly compressed teeth with no-faceted labial surfaces (Young \& Andrade, 2009; Andrade et al., 2010).

Among geosaurinis, the tooth enamel ornamentations make of Torvoneustes a peculiar member. In this genus, the basal halfthird of the crown shows conspicuous, long, and apicobasally 
aligned ridges, whereas its crown apex is covered with short, discontinuous, and flattened tubercles that are stacked together displaying the "anastomosed pattern" described by Young et al. (2013b, p. 823). Now, the tooth enamel ornamentation of Torvoneustes is also known in IGM 9026 (Figures 2A$\mathrm{B})$; consequently, this specimen is reassigned to the genus Torvoneustes. Similar tooth enamel ornamentations are present in at least two teleosaurids, Machimosaurus von Meyer, 1837, and "Steneosaurus" obtusidens Geoffroy Saint-Hilaire, 1825; in these semiaquatic crocodylomorphs, the tooth carinae are heterogeneous because its denticles, although true and isomorphic, are poorly defined and discontinuously distributed (Young et al., 2014b, 2015). The carinae pattern found in these teleosaurids contrasts with IGM 9026, because in the latter the homogeneous carinae have true, well-defined, isomorphic and continuously distributed denticles.

Today, the genus Torvoneustes is known by two Kimmeridgian species from the lower Kimmeridge Clay Formation, England, as well as by some Late Oxfordian specimens from England tentatively referred to this genus and that unfortunately lack teeth (Young, 2013). The Kimmeridgian type species are T. carpenteri and T. coryphaeus. Three dental characters are different in these two species. In $T$. carpenteri the tooth crowns are slightly curved backward, slightly laterally compressed (about straight and circular in cross section), and the anastomosed pattern of enamel ornaments in the crown apex extends onto the carinae (Young et al., 2013b). Conversely, in T. coryphaeus the tooth crowns are notably curved, strongly laterally compressed, and its crown apex has a smooth area between the carinae and the anastomosed pattern of tooth enamel (Young et al., 2013b). Although the cross sections of the teeth are unknown in IGM 9026, this specimen shows a distinctive combination of the other two characters; its teeth are strongly curved (as in T. coryphaeus) and the tooth enamel ornamentations form an anastomosed pattern reaching the carinae (as in T. carpenteri). Additionally, IGM 9026 differs from these English species in the tooth apex acuteness; teeth tips in IGM 9026 are particularly sharp while in T. carpenteri and T. coryphaeus these are rather blunt. On the other hand, in IGM 9026 the denticles that shape the microziphodont pattern in the basal part of the teeth are well defined while in T. carpenteri and T. coryphaeus these denticles are poorly defined. Displayed these differences, herein IGM 9026 is recognized as a new species of Torvoneustes, which is named under a new nominal combination as Torvoneustes mexicanus.

Although some of the distinctive tooth characters of Torvoneustes could be linked to the ontogeny, up to date, the number of specimens of the three species of Torvoneustes is extremely low; hence, there are no enough data to characterize the possible ontogenetic changes on teeth of these organisms. In this context, the tooth morphological differences found in the specimens of Torvoneustes cannot be minimized or ignored because these may have real value to identify species. Therefore, considering the actual knowledge on the tooth morphological diversity of this genus, its three nominal species, including Torvoneustes mexicanus comb. nov., are enough different to each other to be considered as valid species.

\section{DISCUSSION}

\section{The losts Wieland's site}

Wieland (1910, p. 361-362) provided some clues about the collection site of specimen IGM 9026, which occurred in "in March 8th of 1909 by at a point north of the way to Putla town, about $6 \mathrm{~km}$ south-southwest from Tlaxiaco town, Oaxaca" (Buchy, 2008b). Although the age of this specimen was originally considered as Cretaceous, it was later considered more likely to be Jurassic (Reynoso, 2006; Buchy, 2008b; among others). Given this geographical and temporal uncertainty, the site of IGM 9026 was considered lost. Fortunately, two additional elements recovered in the present work facilitate the recognition of this lost site.

On the one hand, both nominal species previously described of Torvoneustes are restricted to the Kimmeridgian age; this suggests that $T$. mexicanus may be of the same age. On the other hand, the recently paleontological prospection along Tlaxiaco Basin has provided a more detailed picture about the geology near the Tlaxiaco town (Alvarado-Ortega et al., 2014; Barrientos-Lara et al., 2015). The Figure 4 presents a geological map of the south-southwest area of Tlaxiaco town, showing that the Kimmeridgian geological unit corresponds to the Sabinal Formation where numerous remains of marine invertebrates and vertebrates (including metriorhynchids) have been collected. Regarding the possible Kimmeridgian age of T. mexicanus and those " $6 \mathrm{~km}$ southsouthwest from Tlaxiaco town" reported by Wieland (1910), it is easy to locate the potential collection site of IGM 9026 along the outcrops of the Sabinal Formation, into a small area of this map. Hence, the collecting site of IGM 9026 is potentially within an area smaller than one $\mathrm{km}^{2}$, located just 3 $\mathrm{km}$ southwest of La Lobera and Yosobé, two rich fossiliferous sites recently reported by Alvarado-Ortega et al. (2014) and Barrientos-Lara et al. (2015).

It is also remarkable that along the entire Tlaxiaco Basin, the tridimensional preservation and cream-coloured clay matrix of IGM 9026 are similar to those found in some marine vertebrate specimens from the Llano Yosobé. Recently, Alvarado-Ortega et al. (2014) described this site near Tlaxiaco town and reported the finding of numerous Kimmeridgian invertebrate and vertebrate fossils preserved into peculiar calcareous nodules present in a $30 \mathrm{~m}$ thick section belonging to the Sabinal Formation. Outcrops of this geological section extends along the ancient Tlaxiaco-Putla road where Wieland (1910) collected the specimen IGM 9026.

\section{Biogeographic importance of Torvoneustes mexicanus}

The Hispanic Corridor is a marine pathway between the western Tethys Sea and Pacific Ocean opened during the Jurassic breakup of the supercontinent Pangaea (Damborenea, 2000; Damborenea et al., 2013). The opening of this corridor was an important paleogeographic event that impacted on the composition and distribution of the Jurassic and Cretaceous 


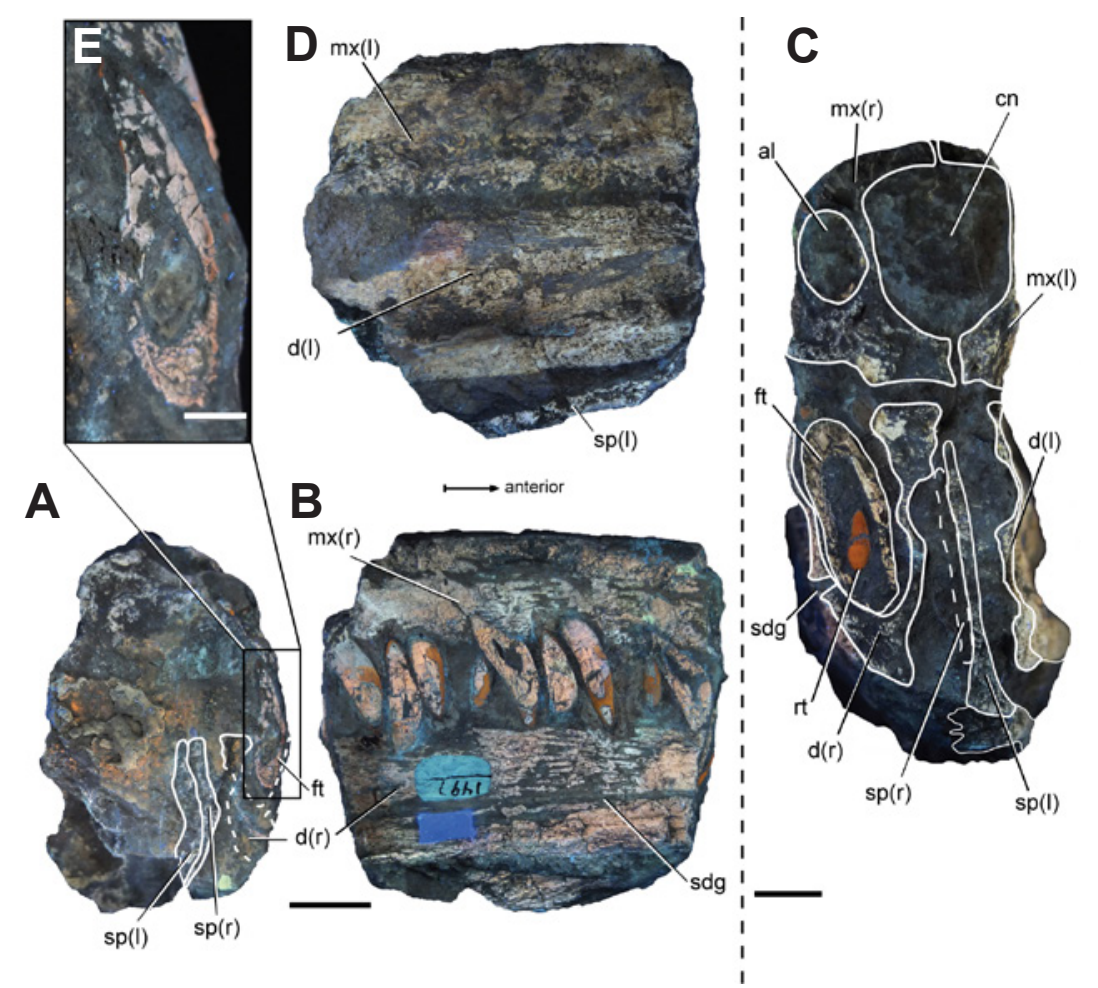

Figure 1. A-E, IGM 9026, Torvoneustes mexicanus comb. nov. under UV light in posterior (A), right lateral (B), anterior (C), left lateral (D) views. E, close-up of the cross section of a dentary tooth. Abbreviations: $\mathbf{c n}$, nasal cavity; $\mathbf{d}$, dentary; fm, functional tooth; $\mathbf{m x}$, maxilla; sdg, surangulodentary groove; rt, replacement tooth; sp, splenial; al, alveolus. Arrows show the anterior end of the specimen. Scale bars: A-B, $\mathrm{D}=20 \mathrm{~mm} ; \mathrm{C}=10 \mathrm{~mm} ; \mathrm{E}=5 \mathrm{~mm}$.

marine faunas because this was an important migration route. Its effects on the biogeographical patterns of some benthonic invertebrates began in the Early Jurassic (e.g. Boomer \& Ballent, 1996); however, it has influence on the distribution of pelagic invertebrates until the late Middle or even Late Jurassic (Damborenea, 2000; Aberhan, 2001). This corridor also was a dispersion route for many pelagic marine reptiles (plesiosaurs, ichthyosaurs, and marine crocodylomorphs) since the Oxfordian (Gasparini \& Iturralde-Vinent, 2006).

During the Jurassic, the Tlaxiaco Basin was a depocenter for continental and marine sediments. To the northeast, it was connected to a wide Mexican epicontinental sea and to the Gulf of Mexico, which then constituted the Western Domain of the Tethys Sea. Marine deposits in this basin also were fed from the west by the Pacific Ocean. Thus, the marine fossils of the Tlaxiaco Basin represent an important expression of the Jurassic paleodiversity and the biogeographic processes attributed to the Hispanic Corridor. The discovery of marine vertebrates along this basin and the review of its fossils (as the specimen IGM 9026) open the opportunity to lern more about such historical patterns and processes (Alvarado-Ortega et al., 2014).

Up to now, the metriorhynchids known from localities along the Hispanic Corridor include two Oxfordian specimens of Cricosaurus and one indeterminate metriorhynchine from the Jagua Formation in Cuba (Iturralde-Vinent \& Ceballos Izquierdo, 2015); the Mexican Kimmeridgian-Tithonian metriorhynchids mentioned above that belong to Cricosaurus, Dakosaurus, and a large number of indeterminate fossils. To this list we can now add Torvoneustes mexicanus nov. comb. that is described in this paper.
This last record is important because Torvoneustes represents an additional Kimmeridgian faunistic element in the Hispanic Corridor that complements our knowledge on the temporal and geographical distribution of Jurassic marine vertebrates.

The recently description of Zoneait nargorum in Oregon, and the discovery of its sister relationship with the family Metriorhynchidae (Wilberg, 2015), opens the possibility that this family could be better represented than previously thought in North America since the Middle Jurassic. However, the comparision of the taxonomical diversity of these crocodiles along Europe, South America, and North America is still highly contrasting. In Europe (Germany, Spain, France, England, and Italy), metriorhynchid diversity is the largest and includes at least 22 species of 12 genera, which began to be described since the first half of the 19th century (i.e. Cuvier, 1824). One hundred and fifty years later, Gasparini \& Dellapé (1976) launched the formal study of metriorhynchids in South America (Argentina and Chile), where now are known by six species of four genera. The study of metriorhynchid fossils began only 28 years ago in North America, when Ferrusquía-Villafranca \& Comas (1988) described the first metriorhynchid discovered in Mexico, based on specimens that today seem to be lost. Before the report on the fossil bearing sites near Tlaxiaco (Alvarado-Ortega et al., 2014), only two species (two nominal species of Cricosaurus) and two genera (including the indeterminate specimens of Dakosaurus) were known all along North America.

Although the contrasting regional metriorhynchids diversity noted above may be a bias caused by different 

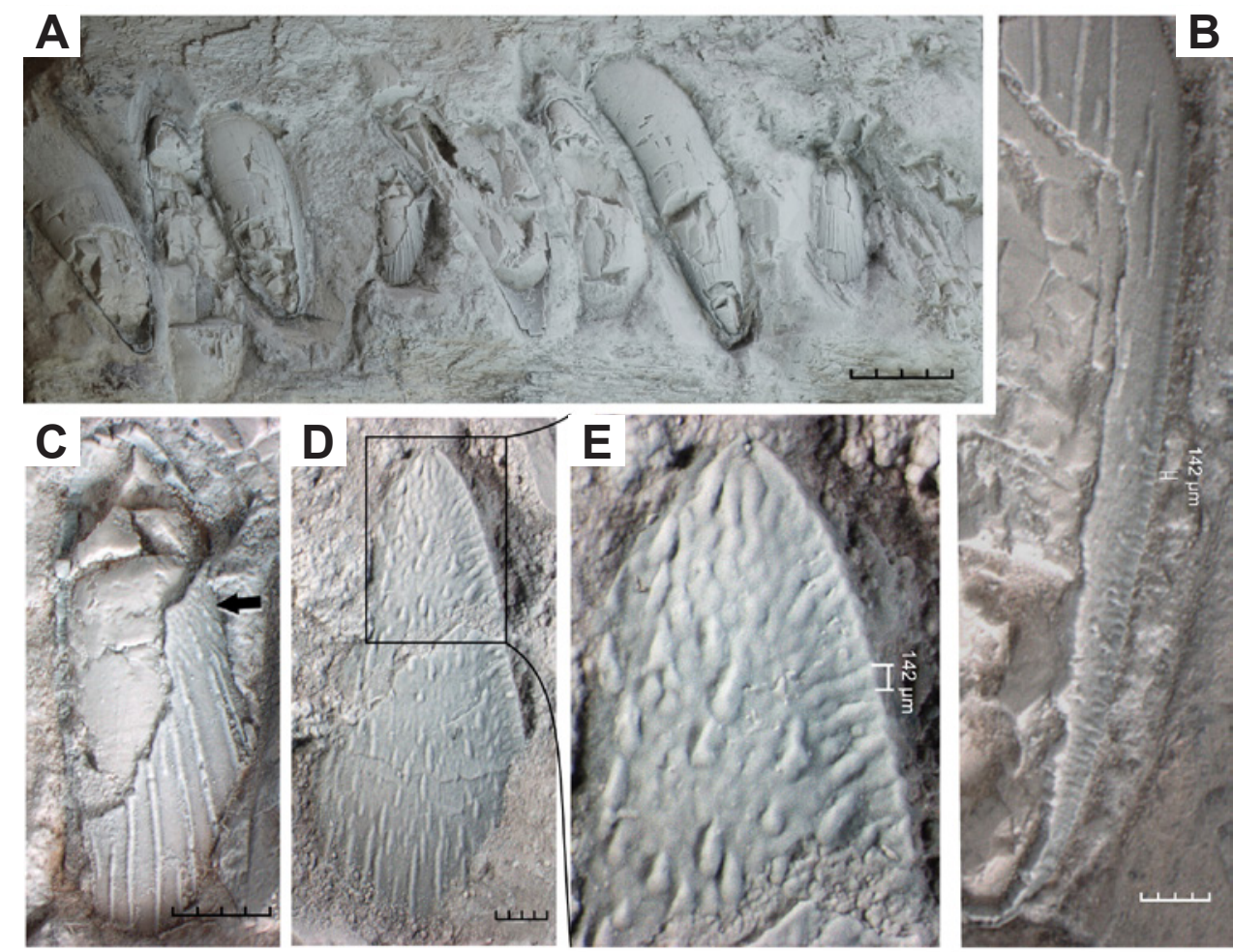

Figure 2. A-E, dental details of IGM 9026, Torvoneustes mexicanus comb. nov.. A, general view of the right teeth; B, maxillary tooth showing the microziphodont condition of the carinae (microscopic isomorphic denticles well defined and evenly distributed); C, dentary tooth showing both tooth enamel ornamentations, the long thick apicobasal ridges at the base and the short, randomly distributed, and anatosmosed dropshaped scabs, extended up to carinae toward the crown apex (indicated for the black arrow); D, replacement dentary tooth showing both tooth enamel ornamentations (compare to $\mathrm{C}$ ) and the acute shape of the crown tip; $\mathbf{E}$, close-up of $\mathrm{C}$ showing the short, randomly distributed and anatosmosed drop shaped tubercles on the crown apex extended up to the tooth borders and the false ziphodont of the carinae in this section. Scale bars: $A=10 \mathrm{~mm} ; B, D=1 \mathrm{~mm} ; C=2 \mathrm{~mm} ; E=142 \mu \mathrm{m}$.

A

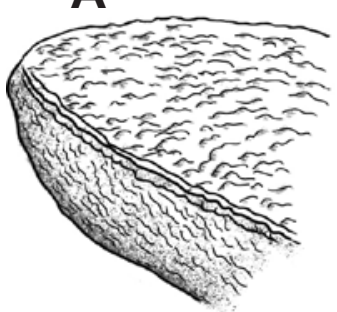

B

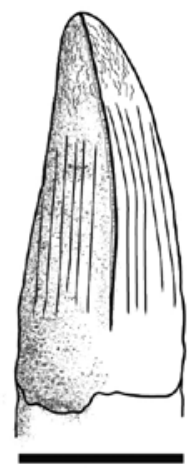

C

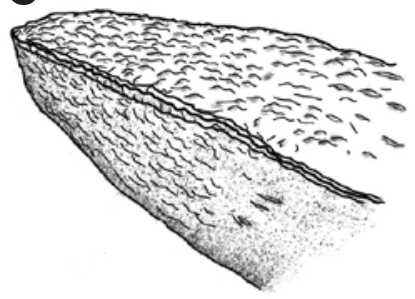

D

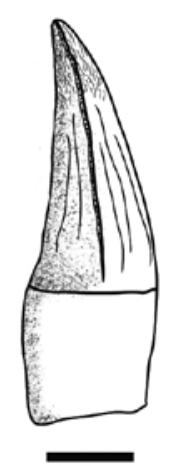

E

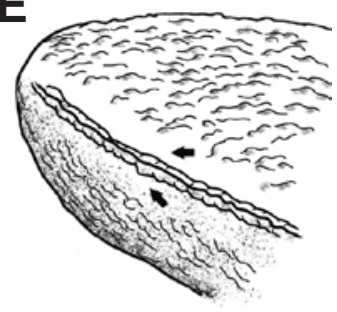

$\mathbf{F}$

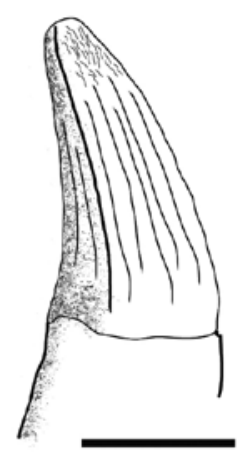

Figure 3. Schematic line drawings of teeth showing the distinctive dental characters of the three nominal species of Torvoneustes, including the accutness of crown apices, the distribution of tooth enamel ornamentations, and the curvature and robustness of the tooth crow. A-B, T. carpenteri, based on BRSMG Cd7203 illustrated by Young et al. (2013a, fig. 26) and Chiarenza et al. (2015, fig. 4); C-D, T. mexicanus comb. nov., based on IGM 9026; E-F, T. coryphaeus, based on MJML K1863 illustrated by Chiarenza et al. (2015, fig. 4). Arrows show the unornamented surface in the tooth crown apex between the carenae and the small anatosmosed drop-shaped scabs. Scale bars: A-B, E-F = $10 \mathrm{~mm}$; C-D = $5 \mathrm{~mm}$. 

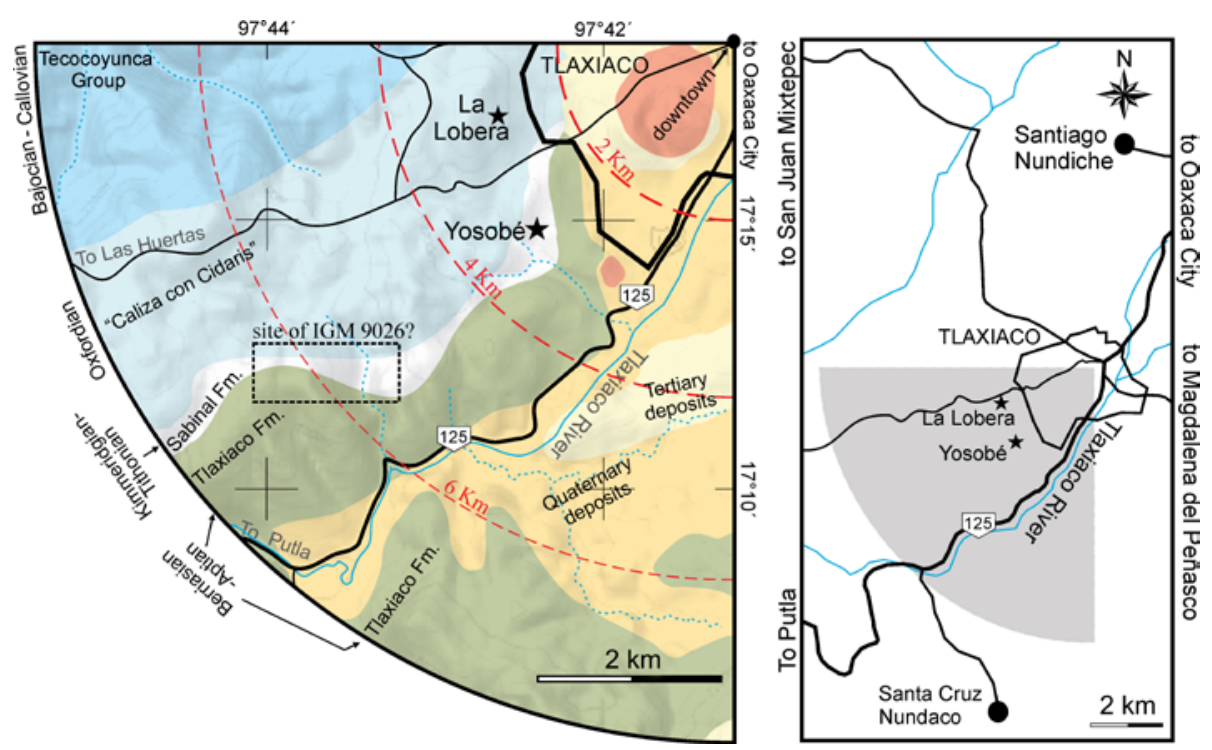

Figure 4. Map of the Tlaxiaco area showing different geological units outcropping in this area of Oaxaca State, Mexico, as well as the potential area where the specimen IGM 9026 was collected by Wieland in 1910 (based on Alvarado-Ortega et al., 2014, fig. 3; Servicio Geológico Mexicano, 2000).

sampling effort in Europe, South America, and North America, a pattern on the geographical distribution of the metriorhynchids is manifest. There are three groups, being two with a restricted regional distribution, one only recognized in South America and other only present in Europe. The third group is widely distributed metriorhynchids, from Europe to South America. The occurrence of Cricosaurus and Dakosaurus into the Caribbean region of North America plays the pivotal role of the Hispanic Corridor in the dispersion of the metriorhynchids. The present finding of Torvoneustes in Mexico reveals a fourth and intermediate metriorhynchid group, which includes taxa that could survive along the entire domain of the Tethys Ocean but were incapable to go beyond the Caribbean region. In this scenario, the Hispanic Corridor also worked as an effective barrier that prevented the dispersion of some metriorhynchids from the Tethys Ocean to the Paleopacific Ocean. We acknowledge that these observations are incomplete, and the proposition of a biogeographical hypothesis of this extinct clade should await the formal study of the metriorhynchids newly discovered in the Yosano Plain (Barrientos-Lara, 2016). This study will also include different vertebrate taxa with European affinities, such as the plesiosaurid Liopleurodon Sauvage, 1873 (BarrientosLara et al., 2015), the fish Pleuropholis cisnerosorum Alvarado-Ortega \& Brito, 2016, as well as platychelyid remains, a sea turtle group present in the Caribbean region and South America (López-Conde, 2016; López-Conde et al., 2015), plus some ophthalmosaurid ichthyosaurs.

\section{CONCLUSIONS}

The present description of IGM 9026, the holotype of Plesiosaurus mexicanus and later tentatively referred as ?Cricosaurus mexicanus, shows enough tooth characters to support its unquestionable belonging to Torvoneustes. Given that IGM 9026 differs from the previous nominal species of this genus, we erected the new combination Torvoneustes mexicanus.

Despite of the collecting site of IGM 9026 was not well established, we consider the coincidence of three independent evidences to suggest their possible location and age. These evidences are: (i) the identification of IGM 9026 as a new species of Torvoneustes, previously known by two English nominal species recovered in Kimmeridgian strata; (ii) the hints left in the little geographical data of IGM 9026 provided by Wieland (1910); and finally, (iii) the recent discovery of a rich Kimmeridgian marine vertebrate assemblage in the LlanoYosobé showing the same preservation features of IGM 9026 . We can now suggest that IGM 9026, holotype of Torvoneustes mexicanus (Wieland, 1910), could have been collected in the Kimmeridgian deposits of the Sabinal Formation.

The occurrence of Torvoneustes in the Tlaxiaco Basin is added to a growing number of vertebrates taxa that show taxonomical similarity between the Western and Eastern domains of the Tethys Sea.

\section{ACKNOWLEDGMENTS}

We owe gratitude to all the local people, university students, and colleagues, who since 2008 have been helping us during the field works and paleontological prospections in the Jurassic fossiliferous sites near Tlaxiaco town. In addition, we thank J.M. Contreras for the photos that illustrate this paper. This work was significantly improved thanks to the comments and suggestions of two anonymous reviewers. Universidad Nacional Autónoma de México, through the PAPIIT projects IN207314, provided the main financial support to this project. Additional supports come from Agencia Nacional de Promoción Científica y Tecnológica (Argentina), project PICTs 2012-0748, 2013-0618, and a Master's degree fellowship from CONACyT (Mexico) provide to JIBL. 


\section{REFERENCES}

Aberhan, M. 2001. Bivalve palaeobiogeography and the Hispanic Corridor: time of opening and effectiveness of a proto-Atlantic seaway. Palaeogeography, Palaeoclimatology, Palaeoecology, 165:375-394. doi:10.1016/S0031-0182(00)00172-3

Alvarado-Ortega, J.; Barrientos-Lara, J.I.; Espinosa-Arrubarrena, L. \& Melgarejo-Damián, M.P. 2014. Late Jurassic marine vertebrates from Tlaxiaco, Oaxaca State, southern Mexico. Palaeontologia Electronica, 17:24A.

Alvarado-Ortega, J. \& Brito, P.M. 2016. A Jurassic pleuropholid fish (Teleostei, Pleuropholidae) in the North American domain of the Tethys Sea. Journal of Vertebrate Paleontology, 36:e1201767. doi:10.1080/02724634.2016.1201767

Andrade, M.B.; Young, M.T.; Desojo, J.B. \& Brusatte, S. 2010. The evolution of extreme hypercarnivory in Metriorhynchidae (Mesoeucrocodylia: Thalattosuchia) based on evidence from microscopic denticle morphology. Journal of Vertebrate Paleontology,30:1451-1465. doi:10.108/02724634.2010.501442

Andrews, C.W. 1913. A descriptive catalogue of the marine reptiles of the Oxford Clay. Part two. British Museum (Natural History), London, $206 \mathrm{p}$.

Barrientos-Lara, J.I. 2016. Los metriorrínquidos (Metriorhynchidae, Thalattosuchia) de la Formación Sabinal (Jurásico Superior, Kimeridgiano) de Tlaxiaco, Oaxaca. Posgrado en Ciencias Biológicas, Universidad Nacional Autónoma de México, 147 p.

Barrientos-Lara, J.I.; Fernández, M.S. \& Alvarado-Ortega, J. 2015. Kimmeridgian pliosaurids (Sauropterygia, Plesiosauria) from Tlaxiaco, Oaxaca, southern Mexico. Revista Mexicana de Ciencias Geológicas, 32:293-304.

Boomer, I. \& Ballent, S. 1996. Early-Middle Jurassic ostracod migration between the northern and southern hemispheres: further evidence for a proto Atlantic-Central America connection. Palaeogeography, Palaeoclimatology, Palaeoecology, 121:5364. doi:10.1016/0031-0182(95)00049-6

Buchy, M.C. 2007. Mesozoic marine reptiles from northeast Mexico: description, systematics, assemblages and palaeobiogeography. University of Karlsruhe, Ph.D. Thesis, 87 p.

Buchy, M.C. 2008a. New occurrence of the genus Dakosaurus (Reptilia, Thalattosuchia) in the Upper Jurassic of north-eastern Mexico, with comments upon skull architecture of Dakosaurus and Geosaurus. Neues Jahrbuch für Geologie und PaläontologieAbhandlungen, 249:1-8. doi:10.1127/0077-7749/2008/0249-0001

Buchy, M. C. 2008b. Reevaluation of the holotype of Plesiosaurus (Polyptychodon) mexicanus Wieland, 1910 from the? Upper Jurassic of Mexico: a thalattosuchian, not a sauropterygian. Revista Mexicana de Ciencias Geológicas, 25:517-522.

Buchy, M.-C.; Stinnesbeck, W.; Frey, E. \& González, A.H. 2007. Première mention du genre Dakosaurus (Crocodyliformes, Thalattosuchia) dans le Jurassique supérieur du Mexique. Bulletin Société Géologique de France, 178:63-69.

Buchy, M.C.; Vignaud, P.; Frey, E.; Stinnesbeck, W. \& González, A.H. 2006. A new thalattosuchian crocodyliform from the Tithonian (Upper Jurassic) of northeastern Mexico. Comptes Rendus Palevol, 5:785-794. doi:10.1016/j.crpv.2006.03.003

Buchy, M.-C.; Young, M.T. \& Andrade, M.B. 2013. A new specimen of Cricosaurus saltillensis (Crocodylomorpha: Metriorhynchidae) from the Upper Jurassic of Mexico: evidence for craniofacial convergence within Metriorhynchidae. Oryctos, 10:9-21.

Cau, A. \& Fanti F, 2011. The oldest known metriorhynchid crocodilian from the Middle Jurassic of North-eastern Italy: Neptunidraco ammoniticus gen. et sp. nov. Gondwana Research, 19:550-565.

Chiarenza, A.A.; Foffa, D.; Young, M.T.; Insacco, G.; Cau, A.; Carnevale, G. \& Catazariti, R. 2015. The youngest record of matriorhynchid crocodylomorphs, with implications for the extinction of Thalattosuchia. Cretaceous Research, 56:608-616.

Cuvier, G. 1824. Article IV Des os de deux espèces inconnues de Gavials; trouvés pêle-mêle près d'Honfleur et du Havre. Sur les Ossemens Fossiles. Nouvelle e'dition, Tome Cinquieme, Partie 2, Paris, Dufour \& d'Occagne, 143-160.

Damborenea, S. 2000. Hispanic Corridor: its evolution and the biogeography of bivalve mollusks. In: R.L. Hall \& P.L. Smith (eds.) Advances in Jurassic Research 2000, GeoResearch Forum 6, p. 369-380.

Damborenea, S.E.; Echevarría, J. \& Ros, S. 2013. Southern Hemisphere paleobiogeography of Triassic-Jurassic marine bivalves. Springer, Dordrecht, $141 \mathrm{p}$.

Debelmas, J. \& Strannoloubsky, A. 1957. Découverte d'un crocodilien dans le Néocomien de La Martre (Var) Dacosaurus lapparenti n. sp.. Travaux du Laboratoire de la Faculté des Sciences de l, Université de Grenoble, 33:89-99.

Eudes-Deslongchamps, E. 1867-1869. Notes Paléontologiques. Caen and Paris, Le Blanc Hardel et Savy, p. 320-392.

Fraas, E. 1902. Die Meer-Crocodilier (Thalattosuchia) des Oberen Juraunter specieller Berücksichtigung von Dacosaurus und Geosaurus. Palaentographica, 49:1-79.

Fernández, M. \& Gasparini, Z. 2000. Salt glands in Tithonian metriorhynchid crocodyliform and their physiological significance. Lethaia, 33:269-276.

Ferrusquía-Villafranca, I. \& Comas, O. 1988. Reptiles marinos mesozoicos en el surest de México y sus significación geológocapaleontológica. Instituto de Geología, Revista, 7:168-181.

Fitzinger, L.J.F.J. 1843. Systema Reptilium. Wien, Braumüller et Seidel, $106 \mathrm{p}$.

Frey, E.; Buchy, M.-C.; Stinnesbeck, W. \& López-Oliva, J.G. 2002. Geosaurus vignaudi n. sp. (Crocodyliformes: Thalattosuchia), first evidence of metriorhynchid crocodilians in the late Jurassic (Tithonian) of central-east Mexico (State of Puebla). Canadian Journal of Earth Sciences, 39:1467-1483. doi:10.1139/e02-060

Gasparini, Z. \& Chong Díaz, G. 1977. Metriorhynchus casamiquelai n. sp. (Crocodilia, Thalattosuchia) a marine crocodile from the Jurassic (Callovian) of Chile, South America. Neues Jahrbuch für Geologie und Paläontologie, Abhandlungen, 153:341-360.

Gasparini, Z. \& Dellapé, D. 1976. Un nuevo cocodrilo marino (Thalattosuchia, Metriorhynchidae) de la Formación Vaca Muerta (Tithoniano) de la provincial de Neuquén (Argentina). In: CONGRESO GEOLÓGICO CHILENO, 1, 1976. Actas, Santiago, p. C1-C21.

Gasparini, Z. \& Iturraide-Vinent, M. 2001. Metriorhynchid crocodiles (Crocodyliformes) from the Oxfordian of western Cuba. Neues Jahrbuch fur Geologie und PalaontologieMonatshefte, 9:534-542.

Gasparini, Z.B. \& Iturralde-Vinent, M. 2006. The Cuban Oxfordian herpetofauna in the Caribbean Seaway. Neues Jahrbuch für Geologie und Paläontologie, Abhandlungen, 240: 343-371. doi:10.1127/njgpa/240/2006/343

Geoffroy Saint-Hilaire, É. 1825. Recherches sur l'organisation des Gavials, sur leurs affinités naturelles desquelles résulte la necessité d'une autre distribution générique: Gavialis, Teleosaurus, Steneosaurus. Mémoires du Muséum national d'Histoire naturelle, 12:97-155.

Herrera, Y.; Fernández, M.S. \& Gasparini, Z. 2013. The snout of Cricosaurus araucanensis: a case study in novel anatomy of the nasal region of metriorhynchids. Lethaia, 46:331-340. doi:10.1111/let.12011

Herrera, Y.; Gasparini, Z. \& Fernández, M.S. 2015. Purranisaurus potens Rusconi, an enigmatic metriorhynchid from the Late Jurassic-Early Cretaceous of the Neuquén Basin. Journal of Vertebrate Paleontology, 35:e904790. doi:10.1080/02724634 .2014.904790 
Hua, S. \& Buffrenil, V. 1996. Bone histology as a clue in the interpretation of functional adaptations in the Thalattosuchia (Reptilia, Crocodylia). Journal of Vertebrate Paleontology, 16:703-717.

Hulke, J.W. 1870. Note on a crocodilian skull from Kimmeridge Bay, Dorset. Quarterly journal of the Geological Society of London, 26:167-172.

International Commission on Zoological Nomenclature. 1999. International Code of Zoological Nomenclature. $4^{\mathrm{a}} \mathrm{ed}$. London, The International Trust for Zoological Nomenclature, The Natural History Museum, $160 \mathrm{p}$.

Iturralde-Vinent, M.; \& Ceballos Izquierdo, Y. 2015. Catalogue of Late Jurassic vertebrates (Pisces, Reptilian) specimens from Western Cuba. Paleontología Mexicana, 3:24-39.

López-Conde, O.A. 2016. Determinación taxonómica de las Tortugas fósiles del Kimmeridgiano de la Formación Sabinal, Tlaxiaco, Oaxaca, México. Posgrado en Ciencias Biológicas, Universidad Nacional Autónoma de México, M.Sc. thesis, 81 p.

López-Conde, O.A.; Sterli, J. \& Alvarado-Ortega, J. 2015. The oldest record of Turtles in Mexico (Late Jurassic, Sabinal Formation, Oaxaca). Journal of Vertebrate Palerontology, 35:167.

Lydekker, R. 1889. On the remains and affinities of five genera of Mesozoic reptiles. Quarterly Journal of the Geological Society, 45:41-59.

Meyer, C.E.H. 1837. Mitteilungen, a Professor Bronn gerichtet. Neues Jahrbuch für Mineralogie, Geognosie, Geologie und Petrefaktenkunde, 4:413-418.

Parrilla-Bel, J.; Young, M.T.; Moreno-Azanza, M. \& Canudo, J.I.; 2013. The first metriorhynchid crocodylomorph from the Middle Jurassic of Spain, with implications for evolution of the subclade rhacheosaurini. PLoSONE, 8:e54275. doi:10.1371/ journal.pone.0054275

Pol, D. \& Gasparini, Z.; 2009. Skull anatomy of Dakosaurus andinensis (Thalattosuchia: Crocodylomorpha) and the phylogenetic position of Thalattosuchia. Journal of Systematic Palaeontology, 7:163-197.

Prasad, G.V.R. \& Broin, F.L. 2002. Late Cretaceous crocodile remains from Naskal (India): comparisons and biogeographic affinities. Annales de Paléontologie, 88:19-71. doi:10.1016/ S0753-3969(02)01036-4

Quenstedt, F.A. 1843. Das Flötzgebirge Württembergs: mit besonderer rücksicht auf den Jura. Tübingen, Laupp, 493 p.

Reynoso, V. H. 2006. Research on fossil amphibians and reptiles in Mexico, from 1869 to early 2004 (including marine forms but excluding pterosaurs, dinosaurs, and obviously, birds). In: F.J. Vega; T.G. Nyborg; M.C. Perrilliat; M. Montellano-Ballesteros; S.R.S. Cevallos-Ferriz \& S.A. Quiroz-Barroso (eds.) Studies on Mexican Paleontology, Dordrecht, Springer, p. 209-231 (Topics on Geobiology 24).

Ruiz-Omeñaca, J.I.; Pinuela L. \& García-Ramos, J.C. 2010. Dakosaurus sp. (Thalattosuchia: Metriorhynchidae) en el Kimmeridgiense de Colunga (Asturias)/Dakosaurus sp. (Thalattosuchia: Metriorhynchidae) in the Kimmeridgian of Colunga (Asturias, northern Spain). In: CONGRESO DEL JURÁSICO DE ESPAÑA, 5, 2010. Comunicaciones, Colunga, p. 193-199.

Rusconi, C. 1948. Nuevo plesiosaurio, pez y langosta de mar jurásico de Mendoza. Revista del Museo de Historia Natural de Mendoza, 2:3-12.

Sauvage, M.H.E. 1873. Note sur les reptiles fossils. Bulletin de la Société Géologique de France, 3:365-380.

Servicio Geológico Mexicano. 2000. Carta Geológico-Minera, Tlaxiaco E32-D34, 1:50 000. Servicio Geológico Mexicano y Secretaría de Economía, México.

Vignaud, P. \& Gasparini,Z., 1996. New Dakosaurus (Crocodylomorpha, Thalattosuchia) in the Upper Jurassic of Argentina. Comptes Rendus de l'Acadénie de Sciences 322:245-250.
Wagner, A. 1858. Zur Kenntniss der Saurier aus den lithographischen Schiefern. Abhandlungen der Mathemat.-Physikalischen Classe der Königlich Bayerischen Akademie der Wissenschaften, 8:415-528.

Wieland, G.R. 1910. Plesiosaurus (Polyptychodon) mexicanus Wieland. Parergones del Instituto Geológico de México, 3:359-365.

Wilberg, E.W. 2015. A new metriorhynchoid (Crocodylomorpha, Thalattosuchia) from the Middle Jurassic of Oregon and the evolutionary timing of marine adaptations in thalattosuchian crocodylomorphs. Journal of Vertebrate Paleontology, 35:e902846. doi:10.1080/02724634.2014.902846

Wilkinson, L.E.; Young, M.T.\& Benton, M.J. 2008.Anew metriorhynchid crocodilian (Mesoeucrocodylia: Thalattosuchia) from the Kimmeridgian (Upper Jurassic) of Wiltshire, UK. Palaeontology, 51:1307-1333. doi:10.1111/j.1475-4983.2008.00818.x

Young, C.C. 1948. Fossil crocodiles in China, with notes on dinosaurian remains associated with the Kansu crocodiles. Bulletin of the Geological Society of China, 28:225-288. doi:10.1111/j.1755-6724.1948.mp283-4011.x

Young, M.T. 2013. Filling the 'Corallian Gap': re-description of a metriorhynchid crocodylomorph from the Oxfordian (late Jurassic) of Headington, England. Historical Biology, 26:80-90. doi:10.1080/08912963.2012.760559

Young, M.T. \& Andrade, M.B. 2009. What is Geosaurus? Redescription of Geosaurus giganteus (Thalattosuchia: Metriorhynchidae) from the Upper Jurassic of Bayern, Germany. Zoological Journal of the Linnean Society, 157:551-585.

Young, M.T.; Andrade, M.B.; Brusatte, S.L.; Sakamoto, M. \& Liston, J. 2013a. The oldest known metriorhynchid super-predator: a new genus and species from the Middle Jurassic of England, with implications for serration and mandibular evolution in predacious clades. Journal of Systematic Palaeontology, 11:475-513. doi:10.1080/14772019.2012.704948

Young M. T.; Andrade M. B.; Cornée J-J.; Steel L. \& Foffa D. 2014a. Re-description of a putative Early Cretaceous "teleosaurid" from France, with implications for the survival of metriorhynchids and teleosaurids across the Jurassic-Cretaceous Boundary. Annales de Paléontologie, 100:165-174. doi.org/10.1016/j.annpal.2014.01.002

Young, M.T.; Andrade, M.B.; Etches, S. \& Beatty, B.L. 2013b. Anew metriorhynchid crocodylomorph from the Lower Kimmeridge Clay Formation (Late Jurassic) of England, with implications for the evolution of dermatocranium ornamentation in Geosaurini. Zoological Journal of the Linnean Society, 169:820-848. doi:10.1111/zoj.12082

Young, M.T.; Beatty, B.L.; Brusatte, S.L. \& Steel, L. 2015. First evidence of denticulated dentition in teleosaurid crocodylomorphs. Acta Palaeontologica Polonica, 60:661-671.

Young, M.T.; Brusatte, S.L.; Andrade, M.B.; Desojo, J.B.; Beatty, B.L.; Steel, L.; Fernández, M.S.; Sakamoto, M.; Ruiz-Omeñaca, J.I. \& Schoch, R.R. 2012. The cranial osteology and feeding ecology of the Metriorhynchid Crocodylomorph genera Dakosaurus and Plesiosuchus from the Late Jurassic of Europe. PLoS ONE, 7:e44985. doi:10.1371/ journal.pone.0044985

Young, M.T.; Brusatte, S.L.; Ruta, M. \& Andrade, M.B. 2010. The evolution of Metriorhynchoidea (Mesoeucrocodylia, Thalattosuchia): an integrated approach using geometric morphometrics, analysis of disparity and biomechanics. Zoological Journal of the Linnean Society, 158:801-859. doi:10.1111/j.1096-3642.2009.00571.x

Young, M.T.; Steel, L.; Brusatte, S.L.; Foffa, D. \& Lepage, Y. 2014 b. Tooth serration morphologies in the genus Machimosaurus (Crocodylomorpha, Thalattosuchia) from the Late Jurassic of Europe. Royal Society Open Science, 1:140269. doi:10.1098/ rsos. 140269

Received in January, 2016; accepted in November, 2016. 